\title{
Cluster analysis of Dairy Herd Improvement data to discover trends in performance characteristics in large Upper Midwest dairy herds
}

\author{
R. L. Brotzman, N. B. Cook, K. Nordlund, T. B. Bennett, A. Gomez Rivas, and D. Döpfer ${ }^{1}$ \\ School of Veterinary Medicine, University of Wisconsin, 2015 Linden Drive, Madison 53706
}

\begin{abstract}
Principal component analysis (PCA) is a variable reduction method used on over-parameterized data sets with a vast number of variables and a limited number of observations, such as Dairy Herd Improvement (DHI) data, to select subsets of variables that describe the largest amount of variance. Cluster analysis (CA) segregates objects, in this case dairy herds, into groups based upon similarity in multiple characteristics simultaneously. This project aimed to apply PCA to discover the subset of most meaningful DHI variables and to discover groupings of dairy herds with similar performance characteristics. Year 2011 DHI data was obtained for 557 Upper Midwest herds with test-day mean $\geq 200$ cows (assumed mostly freestall housed), that remained on test for the entire year. The PCA reduced an initial list of 22 variables to 16 . The average distance method of CA grouped farms based on best goodness of fit determined by the minimum cophenetic distance. Six groupings provided the optimal fitting number of clusters. Descriptive statistics for the 16 variables were computed per group. On observations of means, groups 1,2, and 6 demonstrated the best performances in most variables, including energy-corrected milk, linear somatic cell score (log of somatic cell count), dry period intramammary infection cure rate, new intramammary infection risk, risk of subclinical intramammary infection at first test, age at first calving, days in milk, and Transition Cow Index. Groups 3, 4 , and 5 demonstrated the worst mean performances in most the PCA-selected variables, including DIM, age at first calving, risk of subclinical intramammary infection at first test, and dry period intramammary infection cure rate. Groups 4 and 5 also had the worst mean herd performances in energy-corrected milk, Transition Cow Index, linear somatic cell score, and new intramammary infection risk. Further investigation will be conducted to reveal patterns of management associated with herd categorization. The PCA and CA should be used when
\end{abstract}

Received May 15, 2014.

Accepted January 12, 2015.

${ }^{1}$ Corresponding author: dopferd@vetmed.wisc.edu describing the multivariate performance of dairy herds and whenever working with over-parameterized data sets, such as DHI databases.

Key words: principal component analysis, cluster analysis, Dairy Herd Improvement data

\section{INTRODUCTION}

As dairy producers continue to strive toward maximizing herd profitability through excellent herd performance, they must consider many different practices and technologies and their potential influence. Indeed, overall herd performance may be measured by numerous different metrics targeted at monitoring milk production, reproductive efficiency, cow health, and longevity. A vast number of routinely collected DHI test-day variables are available to describe many aspects of production and performance. Whereas it would be a relatively simple task to rank herds based on a single variable characterizing milk production, SCC, reproduction parameters, or culling rates, no single DHI variable entirely encompasses the overall performance of a herd. Furthermore, many DHI variables are associated with herd size. Larger herds produce more milk per cow than smaller herds (Mayer and Kammel, 2008; Oleggini et al., 2001; USDA NASS, 2010); therefore, selecting herds based on milk production alone would result in a biased sample of primarily only the largest herds. Although it may seem economically appropriate to use a standardized milk production parameter such as rolling herd FCM as a measure of success (Enevoldsen et al., 1996), milk production is not always positively associated with preferred outcomes of all production variables, such as measures of reproductive efficiency (Pecsok et al., 1992). In addition, the associations change with herd size and region (Lucy, 2001; Oleggini et al., 2001).

The processes and outcomes of milk production, reproduction, health, herd size, and management strategies are interconnected, and the need to optimize each area for the most efficient use of limited resources on farms for maximum profit adds a level of complexity (Enevoldsen et al., 1995; Galligan, 1999, 2006). To further complicate these decisions, ever-increasing concern 
exists among both consumers and those involved in dairy production over the social responsibilities of increasingly industrialized dairy farms resulting from the push to produce more milk more efficiently (von Keyserlingk et al., 2013). Indeed, $75.6 \%$ of milk produced in the United States in 2012 was produced on dairy farms of 200 or more cows (USDA NASS, 2012), and in Wisconsin, herds of 200 or more cows are most likely to be managed in an intensive manner, with freestall barns, and use of a milking parlor (USDA NASS, 2010).

There is a need to define a method for classifying herds' overall performance that is not biased toward any single descriptive variable. Cluster analysis (CA) offers a method of dividing entities into groups based upon similarity in multiple characteristics simultaneously (Borcard, 2011) and has been used in a variety of dairy cattle research applications (Weigel and Rekaya, 2000; Kirk et al., 2005; Alvarez et al., 2008; Bramley et al., 2008). In so doing, CA provides the ability to sort herds on multiple, diverse DHI variables without preconceived ideas regarding the relationships among the selected variables and their association with management practices. The goal of this project was to categorize large dairy herds into groups with similar performance characteristics over a variety of routinely recorded DHI production parameters. The outcome will facilitate further examination of combinations of management strategies that achieve different profiles of overall performance independent of performance in any single variable (such as herd size). In future manuscripts, strategies linked to overall success or failure of cluster groups will be examined in further detail. To accomplish this, principal component analysis (PCA) was applied to DHI data to determine the most meaningful subset of variables to describe the herds, followed by $\mathrm{CA}$ to categorize the herds into groups in an outcome independent way.

\section{MATERIALS AND METHODS}

The DHI test-day data for 4,190 dairy herds were provided by AgSource Cooperative Services (Verona, WI). Assuming randomness of the following criteria in the data set, herds that began or stopped testing during 2011, herds with missing data for the variables of interest, and those outside of the Upper Midwest (Wisconsin, Illinois, Michigan, Minnesota, and Iowa) were removed, resulting in 3,078 herds retained. Herds with a test-day average $\geq 200$ cows were selected as "large" herds for the final data set of 557 herds of interest, as they were most likely to house cows in a relatively similar, intensive manner, with freestall barns and use of a milking parlor (USDA NASS, 2010). In total, these dairies had 319,934 cows in their herds. SAS version 9.2
(SAS Institute Inc., Cary, NC) was used to compile and edit data and generate descriptive statistics.

Twenty-two herd-level variables were initially selected from the 992 measured and calculated parameters stored in AgSource's database, describing herd level milk production, reproduction, culling, udder health, metabolic health, and genetics. One value for each variable for each herd was calculated as the mean of the variable from 2011 test-day data, with the exception of the variables milking frequency and those describing the proportions of calves born dead, cows culled, cows that died, and cows that died by 60 DIM. These rate measures are calculated by AgSource as the number of affected animals in the past $365 \mathrm{~d}$ divided by the relevant mean population size on test day in the past 365 d (i.e., number of calves born for the stillbirth rate, or lactating and dry cows on test for the culled, died, and died by 60 DIM rates); therefore, the last recorded value in 2011 for each of these rates for each herd was retained for analysis. Milking frequency was a single, recorded variable in the herd descriptive data provided by AgSource. Variable selection criteria included usefulness for characterization of herd health, wellbeing and performance, reliability of recorded data (e.g., services per conception will not be accurate if only the successful service is recorded by a dairy, disposal codes indicate only one of potentially many reasons a cow leaves the herd, and so on), and low pair-wise correlation with other variables of interest based on 2011 testday means (Pearson correlation coefficient, $\mathrm{r}<0.90$ ). Mean count of cows in the herd was log-transformed due to nonnormal distribution. Descriptive statistics of the 22 mean test-day DHI variables for the 557 large dairy herds are summarized in Table 1. Descriptive statistics of the 22 mean test-day DHI variables for the entire AgSource database population are summarized in Table A1 of the Appendix.

The PCA was performed on the 22 variables standardized around their mean among the 557 large Upper Midwest dairy herds to determine the variables that explained above average variance in the data set. Sixteen variables explained above average variance between herds for all combinations in the first 6 principal components. Pearson correlations between the 16 PCAselected variables were calculated using PROC CORR in SAS. No correlations were greater than 0.90 , so all 16 variables were kept for CA. The average distance method for CA was chosen for grouping farms into the final number of clusters based on best goodness of fit, which is the minimum cophenetic distance. The bestfitting number of clusters was determined using Wards partitioning method and Fourier plots, maximum simple structure index, and minimum error sum of squares optimization using the methodology of Borcard (2011). 
Biplots of the principal components 1 and 2 were used to visualize the correlation between the 16 variables and the final number of clusters. Both PCA and CA were completed in R 15.3.1 (R Foundation for Statistical Computing, Vienna, Austria). Descriptive statistics for the 16 selected variables were computed per group using SAS. To further investigate potential differences in each variable between cluster groups, a multivariate ANOVA was performed using PROC GLM in SAS with a Bonferroni correction for multiple comparisons of LSM at an error level $\alpha<0.05$.

\section{RESULTS}

Six clusters best described the data set, with average cophenetic distances between farms within a group being least for this choice of cluster numbers. A biplot in the principal component 1 by 2 plane was found to be more useful in depicting the cluster groups instead of a dendrogram, due to the large number of herds in the data set (Figure 1).

Table 1 describes each of the 6 groups of herds using the 22 variables submitted for use in PCA, with the 16 variables used for $\mathrm{CA}$ designated by an asterisk $(*)$. Groups were not evenly sized, with group 1 consisting of the largest number of herds $(\mathrm{n}=171)$ and group 5 the smallest number of herds $(n=62)$. Ranges in each variable generally overlapped between groups. A Pearson correlation matrix of the $16 \mathrm{PCA}$-selected variables is shown in Table 2. Univariate results of multivariate ANOVA demonstrated a significant effect of each PCAselected variable on group categorization $(P<0.0001)$. Significant differences in LSM between groups in each PCA-selected variable are shown in Table 3.

Many variables subjected to CA showed strong segregation by group. Groups 1 and 6 almost entirely used thrice daily milking versus group 2 farms, which all used twice daily milking. Herds in groups 4 and 5 were also significantly segregated toward 2 and 3 times daily milking, respectively. Groups 1 through 5 had a smaller mean proportion of the herd as primiparous cows, whereas group 6 herds were characterized by a significantly larger mean proportion of primiparous cows (mean $\pm \mathrm{SD} ; 43.8 \pm 5.11 \%$ ). Group 1 demonstrated the highest ECM ( $41.7 \pm 3.5 \mathrm{~kg})$; groups 2,3 , and 6 were similar in production, whereas the lowest mean ECM was found in group $4(33.9 \pm 4.5 \mathrm{~kg})$. Age at first calving (AGE1) did not numerically range widely between groups; however, small but significant LSM differences were present. Group 6 had the lowest AGE1 (23.4 \pm 0.8 mo), followed by groups 1 and $2(24.1 \pm 0.9$ and 24.5 \pm 1.1 mo, respectively), with groups 3 , 4 , and 5 having the highest AGE1. Groups 1 and 2 had the lowest mean linear somatic cell score (LSCS) at $2.2 \pm 0.31$ and
$2.3 \pm 0.3$, respectively. Transition Cow Index (TCI) is a measure of fresh cow performance patented by the Wisconsin Alumni Research Foundation made available through AgSource Cooperative Services. It represents the difference between predicted and actual first test 305-d milk. Mean TCI was highest in group 2 (236.1 \pm $301.9 \mathrm{~kg})$ and $1(207.8 \pm 351.4 \mathrm{~kg})$, with the remaining groups all having negative performances in TCI.

Group 5 herds were markedly highest in mean proportion of herd died $(12.4 \pm 3.6 \%)$, mean proportion of herd died by 60 DIM $(5.7 \pm 2.0 \%)$, and second-highest in mean proportion of herd culled $(40 \pm 6.0 \%)$, whereas group 6 exhibited the highest proportion culled (43 $\pm 8.5 \%$ ). Although numerical differences in means of these herd-turnover variables were apparent among the other 5 groups, the significance of the differences in LSM overlapped from group to group.

Other variables generally did not differ widely between groups, yet significant LSM differences were present. The largest mean herd size was represented by group 6 (1,478 $\pm 1,356$ cows), with a gradient of decreasing mean herd sizes with some similarities between the remaining groups. Groups 3, 4, and 5 had higher mean DIM than groups 1, 2, and 6. Group 3 herds had the shortest mean dry period length $(54.7 \pm 8.2 \mathrm{~d})$, followed closely by group $6(57.0 \pm 6.5 \mathrm{~d})$, whereas the remaining 4 groups were similar. Milk peak ratio (the proportion of peak test-day milk production of primiparous to multiparous cows) was lowest for groups 1 and 2 $(74.4 \pm 3.0$ and $74.1 \pm 3.0$, respectively), intermediate and similar for groups 6 and 5 (74.9 \pm 3.8 and $76.4 \pm$ 3.8 , respectively), and highest for groups 3 and 4 (77.8 \pm 4.3 and $77.6 \pm 4.9$, respectively).

Mean LSCS, mean proportion of herd with a new IMI (NINF; previous test day SCC $<200,000$ and current test day SCC >200,000), mean proportion of herd with a new IMI at first test (SCC at last test of previous lactation $<200,000$ and SCC at first test of current lactation $>200,000$ ), and mean proportion of dry period IMI cured (DC; SCC at last test of previous lactation $>200,000$ and SCC at first test of current lactation $<200,000)$ followed similar patterns between groups, in that group 1 consistently had the best LSM performance in each of these variables, with group 2 being similar in LSCS and NINF. Group 4 consistently had the worst LSM performances in all 4 udder health variables, with group 5 being similar in LSCS and NINF.

Overall, group 1 demonstrated by far the most number of best performances by group in this selection of DHI variables, whereas groups 2 and 6 brought in the second and third highest number of best performances. Group 4 had the highest number of worst performances in this data set, followed by group 5. Group 3 sat in the 


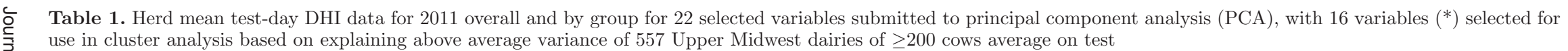

\section{DHI variable ${ }^{1}$}

(mean \pm SD;

median; range)

All herds

Group 1

Group 2

Group 3

Group 4

Group 5

Group 6

\section{*Milking frequency}

$2.7 \pm 0.5$

$3.0 \pm 0.1$

3.0

3.0

*Herd size

2.0-3.0

$574.4 \pm 666.9$
385.7

200.7-8063.9

*LACT1

$39.0 \pm 6.1$

38.8

$2.0 \pm 0$

2.0

$2.9 \pm 0.3$

$2.2 \pm 0.4$

$2.0-2.0$
$300.3+185.7$

470.8

$201.3-2721.3$

$38.4 \pm 4.9$

38.5

21.3-72.1

$21.3-56.0$

$3.7 \pm 0.3$

3.6

3.7
$3.0-5.1$

Milk protein, \%

$3.0-5.1$
$3.0 \pm 0.1$

3.0

$2.8-3.9$
4.4

$39.4 \pm 4.4$

39.7

$$
\text { 19.8-50.4 }
$$

$\mathrm{NM} \$$

$93.1 \pm 57.1$

94.8
$-165.3-307.3$

*DIM

$186.3 \pm 14.7$

184.4

*DDRY

$130.7-298.3$
$58.6 \pm 8.3$

58.0

$32.0-107.2$

*AGE1, mo

$24.5 \pm 1.4$

24.3

21.4-31.4

*TCI, $\mathrm{kg}$

$52.2 \pm 362.5$

$$
48.8
$$

*Milk peak ratio

$-1297.5-1114.6$
$75.6+4.0$

75.3

65.4-92.1

First test $F: P \geq 1.4, \% \quad 38.9 \pm 11.5$

38.1

$10.0-75.8$
$2.5 \pm 0.4$

2.5

$1.1-4.2$
$1+3.7$

10.7

*NINF, \%

10.7
$4.4-29.5$

CINF, \%

\section{$55.3+7.8$}

56.4

$25.0-75.0$

$3.0 \pm 0.1$

3.0

$2.8-3.9$

$41.7 \pm 3.5$

$24.9-50.1$

$104.1 \pm 57$

102

$-158.8-307.3$

$182.9 \pm 10.4$

182.7

162.6-212.2

$59.4 \pm 7.8$

43.7-107.2

$24.1 \pm 0.9$

24.1

21.6-26.3

$207.8 \pm 351.4$

216.1

-686.1-1114.6

$74.4 \pm 3.0$

65.5-81

$38.4 \pm 10.9$

38

10.0-69.9

$2.2 \pm 0.3$

2.2
$1.1-2.9$

$8.7 \pm 1.9$

8.7

4.4-13.2

$53.4 \pm 7.2$
54.3

$29.8-67.8$

250.4

200.8- 1654.9

$38.1 \pm 5.9$

22.1-60.7

$3.7 \pm 0.2$

3.7

$3.2-4.9$
$3.1 \pm 0.1$

3.1

2.8-3.5

$39.4 \pm 3.8$

39.7

26.7-49.5

$89.3 \pm 61.2$
94.2

94.2
$-62.8-240.2$

$179.7 \pm 10.1$

180.5

149.9-201.4

$59.4 \pm 7.5$

59.6
$42.2-80.8$

$24.5 \pm 1.1$

$24.5 \pm$
24.5

21.9-27.2

$236.1 \pm 301.9$

195.9

-366.3-1081

$74.1 \pm 3.0$

65.4-81.5

$40.4 \pm 11.9$

40.7

$11.6-64.7$
$2.3 \pm 0.3$

2.3

$1.7-3.1$

$8.9 \pm 2.3$

4.8-14.6

$53.3 \pm 7.7$

54.1
$25.7-68.4$
3.0

$2.2 \pm 0.4$
2.0

2.0-3.0

$294 \pm 104.2$
252.5

252.5
$200.7-707.3$

$38.0 \pm 7.9$

36.4

$38.6 \pm 5.7$

38.6

25.5-50.6

$3.7 \pm 0.2$
3.7

3.2-4.3

$3.0 \pm 0.1$

3.0
$2.8-3.3$

$40 \pm 3.7$

39.7

31.1-50.4

$87.9 \pm 50.4$

89.9

-40.1-264.7

$195.5 \pm 13.2$

194.6

$169.3-230.6$

$54.7 \pm 8.2$

54.1

34.0-79.4

$25.3 \pm 1.7$

25.1

$21.8-29.5$

$-10.9 \pm 365.5$

51.2

-1297.5-680

$77.8 \pm 4.3$

69.5-90.4

$39.8 \pm 12.1$

39.5

17.7-70.2

$2.6 \pm 0.3$

2.7

1.6-3.4

$11.9 \pm 2$.

5.3-19.4

$56.3 \pm 7.6$

57.0

25.0-69.3
$25.7-72.1$
$3.8 \pm 0.4$
3.7

$3.8 \pm 0.4$
3.7

3.1-5.1

$3.1 \pm 0.2$

3.1
$2.9-3.9$

$33.9 \pm 4.5$

34.2

$$
\text { 19.8-41.7 }
$$

$64.9 \pm 57.8$

68.3

-165.3-182.3

$189.1 \pm 23.6$

185.5

130.7-298.3

$60.7 \pm 10.2$

59.6
$32.0-88.8$

$25.6 \pm 1.8$

25.5

22.8-31.4

$-171.8 \pm 328$.

$-120.2$

$-1073.9-493$
$77.6+4.9$

$7.6 \pm 4.9$
69.2

$69.2-90.6$

$35.8 \pm 12.6$

34.2

$13.2-70.2$

$3.0 \pm 0.4$

3.0

1.9-4.2

$14.7 \pm 4.0$

14.0

$59.1 \pm 7.7$
59.8

59.8

41.4-72

$(\mathrm{n}=62)$

$(\mathrm{n}=74)$

$2.8 \pm 0$

3.0

$3.0 \pm 0.1$

3.0

$\begin{array}{cc}2.0-3.0 & 2.0-3.0 \\ 480.0 \pm 329.5 & 1477.7 \pm 1355.7\end{array}$

411.8

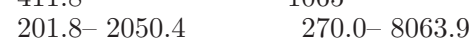

$37.8 \pm 5.9$

38.0

21.6-49.7 $\quad 33.1-55.7$

$3.7 \pm 0.3$

3.7

$3.2-4.9$
$3.1 \pm 0.1$

3.0

$2.9-3.7$
$-9+4.0$

37.1

$26.5-46.1$

$81.0 \pm 59.8$

85.6

$-99.3-223$

$192.5 \pm 16.6$

190.2

$159.4-235.8$
$60.8 \pm 8.6$

60.4

$46.3-88.6$

$24.9 \pm 1.2$

24.7

$22.8-29.8$

$-212.9 \pm 260.8$

$-260.8$

-725.3-342.4

75.8
$68.4-92$

68.4-92.1

$40.0 \pm 12.1$

37.9

14.1-75.8

$2.8 \pm 0.4$

2.8

1.9-4.0

13.5

7.3-28.4

$57.1 \pm 8.1$

58.5

27.0-75.0

$33.1-55$.
$3.7+0.2$
3.6

3.6

3.1-4.9

$3.0 \pm 0.1$

3.0
$2.9-3.5$

$40.2 \pm 3.0$

40.1

32.6-47.7

$114.6 \pm 43.8$ 
Table 1 (Continued). Herd mean test-day DHI data for 2011 overall and by group for 22 selected variables submitted to principal component analysis (PCA), with 16 variables $\left.{ }^{*}\right)$ selected for use in cluster analysis based on explaining above average variance of 557 Upper Midwest dairies of $\geq 200$ cows average on test

\begin{tabular}{|c|c|c|c|c|c|c|c|}
\hline $\begin{array}{l}\text { DHI variable }{ }^{1} \\
\text { (mean } \pm \mathrm{SD} ; \\
\text { median; range) }\end{array}$ & $\begin{array}{l}\text { All herds } \\
(\mathrm{n}=557)\end{array}$ & $\begin{array}{l}\text { Group 1 } \\
(\mathrm{n}=171)\end{array}$ & $\begin{array}{l}\text { Group 2 } \\
(\mathrm{n}=86)\end{array}$ & $\begin{array}{l}\text { Group 3 } \\
(\mathrm{n}=97)\end{array}$ & $\begin{array}{l}\text { Group 4 } \\
(\mathrm{n}=67)\end{array}$ & $\begin{array}{l}\text { Group 5 } \\
(\mathrm{n}=62)\end{array}$ & $\begin{array}{l}\text { Group } 6 \\
(\mathrm{n}=74)\end{array}$ \\
\hline *INF1, \% & $\begin{array}{c}14.5 \pm 4.9 \\
13.9 \\
4.2-32.8\end{array}$ & $\begin{array}{l}11 \pm 3.1 \\
10.9 \\
4.2-20.6\end{array}$ & $\begin{array}{c}13.7 \pm 3.6 \\
13.3 \\
5.1-24\end{array}$ & $\begin{array}{c}15.7 \pm 4.1 \\
15.3 \\
6.3-26.1\end{array}$ & $\begin{array}{c}19.9 \pm 5.2 \\
19.3 \\
8.3-32.8\end{array}$ & $\begin{array}{c}17.8 \pm 4.6 \\
17.3 \\
9.8-29.7\end{array}$ & $\begin{array}{c}14.5 \pm 3.2 \\
14.4 \\
7.7-21.6\end{array}$ \\
\hline$* \mathrm{DC}, \%$ & $\begin{array}{l}67.9 \pm 12.3 \\
70.1 \\
20.0-94.1\end{array}$ & $\begin{array}{c}75.5 \pm 10.0 \\
76.3 \\
37.5-94.1\end{array}$ & $\begin{array}{l}66.4 \pm 11.6 \\
\quad 67.8 \\
37.6-88.2\end{array}$ & $\begin{array}{l}63.9 \pm 9.7 \\
\quad 65.5 \\
38.8-81.6\end{array}$ & $\begin{array}{l}56.5 \pm 14.1 \\
57.2 \\
20.0-82.1\end{array}$ & $\begin{array}{l}63.7 \pm 10.0 \\
\quad 63.9 \\
33.6-90.1\end{array}$ & $\begin{array}{l}71.5 \pm 8.4 \\
71.8 \\
51.5-88.8\end{array}$ \\
\hline${ }^{*}$ CULL, $\%$ & $\begin{array}{l}36.2 \pm 8.3 \\
\quad 36.2 \\
\quad 4.7-72.3\end{array}$ & $\begin{array}{l}33.5 \pm 7.5 \\
\quad 34.1 \\
5.5-50.5\end{array}$ & $\begin{array}{l}36.1 \pm 6.5 \\
\quad 36.0 \\
20.5-49.2\end{array}$ & $\begin{array}{l}35.9 \pm 7.4 \\
\quad 35.8 \\
15.1-59.4\end{array}$ & $\begin{array}{l}32.6 \pm 9.9 \\
32.4 \\
4.7-61.5\end{array}$ & $\begin{array}{l}40.0 \pm 6.0 \\
39.9 \\
27.3-56.9\end{array}$ & $\begin{array}{l}43.0 \pm 8.5 \\
\quad 41.9 \\
26.8-72.3\end{array}$ \\
\hline *DIED, \% & $\begin{array}{l}6.7 \pm 3.6 \\
\quad 6.2 \\
\quad 0.0-20.4\end{array}$ & $\begin{array}{l}5.7 \pm 2.6 \\
\quad 5.4 \\
\quad 0.9-12.6\end{array}$ & $\begin{array}{l}5.7 \pm 2.7 \\
5.4 \\
0.4-15\end{array}$ & $\begin{array}{l}6.3 \pm 3.2 \\
\quad 6.2 \\
\quad 0.3-14.5\end{array}$ & $\begin{array}{l}4.9 \pm 2.6 \\
\quad 4.6 \\
0.0-14.0\end{array}$ & $\begin{array}{l}12.4 \pm 3.6 \\
12.1 \\
4.9-20.4\end{array}$ & $\begin{array}{l}7.6 \pm 2.6 \\
\quad 7.6 \\
1.4-14.0\end{array}$ \\
\hline *DIED60, \% & $\begin{array}{l}2.7 \pm 1.8 \\
\quad 2.3 \\
0.0-12.9\end{array}$ & $\begin{array}{l}2.3 \pm 1.2 \\
\quad 2.1 \\
\quad 0.0-6.6\end{array}$ & $\begin{array}{l}2.7 \pm 1.7 \\
\quad 2.5 \\
\quad 0.0-9.4\end{array}$ & $\begin{array}{l}2.4 \pm 1.5 \\
\quad 2.1 \\
0.0-6.9\end{array}$ & $\begin{array}{c}1.8 \pm 1.1 \\
1.5 \\
0.0-5.4\end{array}$ & $\begin{array}{l}5.7 \pm 2.0 \\
\quad 5.6 \\
\quad 2.3-12.9\end{array}$ & $\begin{array}{l}2.7 \pm 1.2 \\
\quad 2.7 \\
0.6-5.1\end{array}$ \\
\hline $\begin{array}{l}\text { Stillborn calves, } \\
\% \text { of births }\end{array}$ & $\begin{array}{l}7.7 \pm 5.2 \\
\quad 7.6 \\
0.0-100\end{array}$ & $\begin{array}{l}7.2 \pm 2.8 \\
\quad 7.1 \\
0.0-16.6\end{array}$ & $\begin{array}{l}8.1 \pm 3.7 \\
\quad 8.2 \\
\quad 0.0-19.7\end{array}$ & $\begin{array}{l}7.3 \pm 3.5 \\
\quad 7.7 \\
0.0-15.9\end{array}$ & $\begin{array}{l}6.6 \pm 4.1 \\
\quad 6.4 \\
\quad 0.0-17.0\end{array}$ & $\begin{array}{l}8.7 \pm 4.4 \\
\quad 7.9 \\
\quad 0.8-27.6\end{array}$ & $\begin{array}{l}9.0 \pm 11.1 \\
\quad 7.5 \\
\quad 3.6-100\end{array}$ \\
\hline
\end{tabular}

${ }^{1} \mathrm{LACT} 1=$ proportion of the herd as primiparous cows; ECM $=3.5 \%$ ECM; NM $\$=$ genetic evaluation of herd net merit; DDRY $=$ days dry; AGE1 = age at first calving; TCI $=$ Transition Cow Index; milk peak ratio = ratio of peak test day milk production of primiparous to multiparous cows; first test $F: P \geq 1.4=$ proportion of herd with milk fat-toprotein ratio greater than or equal to 1.4 at first test; LSCS = linear somatic cell score (log SCC); NINF = proportion of herd with a new IMI (previous test day SCC <200,000 and current test day SCC > 200,000); CINF = proportion of herd with a chronic IMI (previous test day SCC $>200,000$ and current test day SCC $>200.000$ ): INF1 = proportion of herd with a new IMI at first test (SCC at last test of previous lactation $<200,000$ and SCC at first test of current lactation $>200,000$ ); DC $=$ proportion of dry period IMI cured ( SCC at last test of previous lactation $>200,000$ and SCC at first test of current lactation $<200,000$ ); CULL = proportion of herd culled; DIED = proportion of herd that died; DIED $60=$ proportion of herd that died by 60 DIM. 


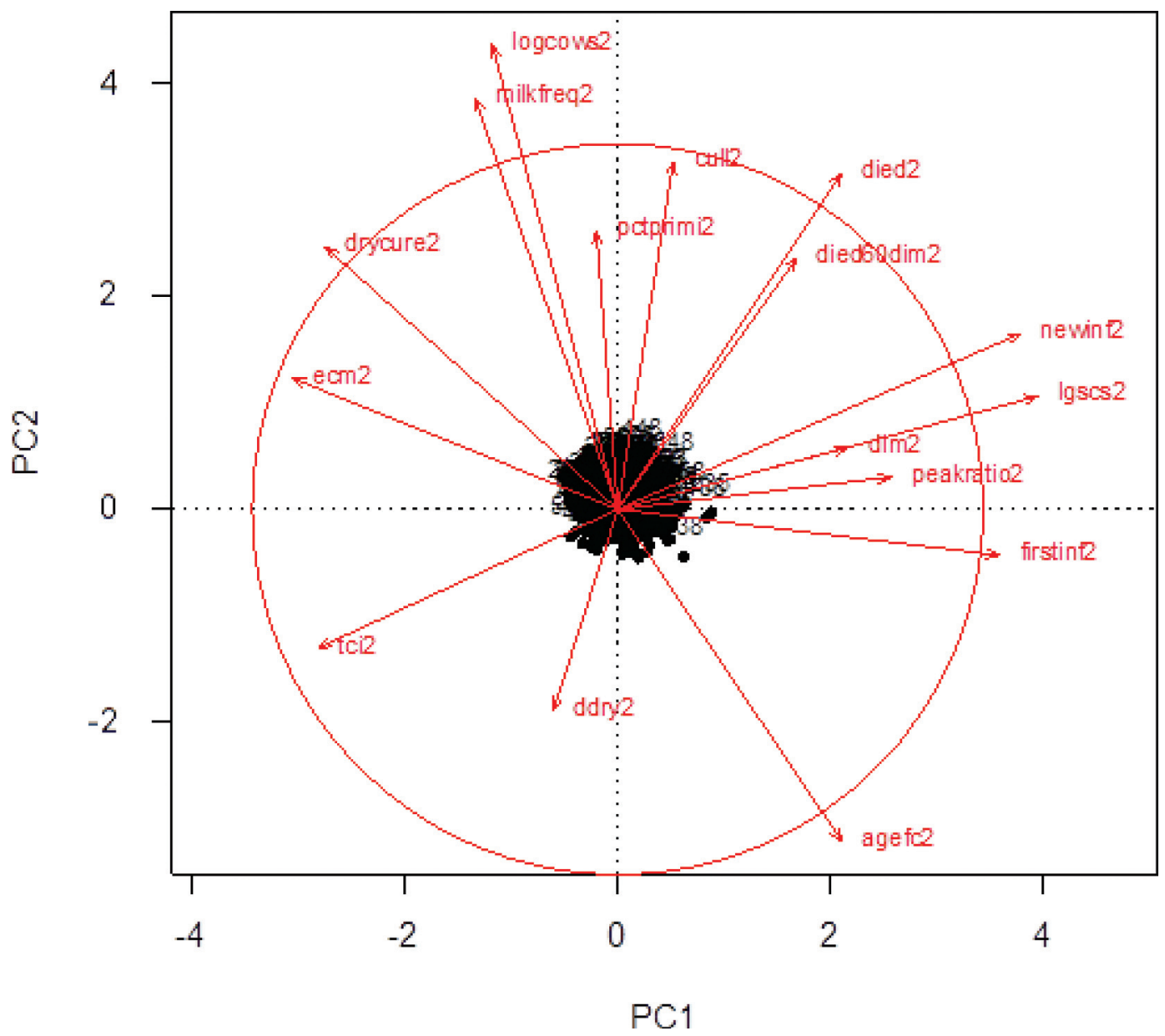

Figure 1. Biplot in the principal component $1(\mathrm{PC} 1)$ and $2(\mathrm{PC} 2)$ plane, depicting the directionality of variables in this 2-dimensional view and the amount of variation (arrow length) explained by each variable standardized around its mean versus the mean of eigen values $(\bigcirc)$ for all standardized variables, which was used as a cutoff point for selecting meaningful variables for describing this data set. Each dot in the center of the graph represents 1 herd (see Figure 2 for detail). logcows $2=\log$ of mean adult cow herd size, standardized; milkfreq $2=$ milking frequency, standardized; pctprimi 2 = mean proportion of primiparous cows, standardized; cull $2=$ mean proportion of herd culled, standardized; died $2=$ mean proportion of herd died, standardized; died60dim2 $=$ mean proportion of herd that died within the first 60 DIM, standardized; newinf2 $=$ proportion of herd with a new IMI (previous test day SCC < 200,000 and current test day SCC >200,000), standardized; lgscs2 = mean linear SCC (log SCC), standardized; dim2 = mean DIM, standardized; peakratio2 = mean proportion of peak test day milk production of primiparous to multiparous cows in the herd, standardized; firstinf2 $=$ proportion of herd with a new IMI at first test (SCC at last test of previous lactation $<200,000$ and SCC at first test of current lactation $>200,000)$, standardized; agefc $2=$ mean age at first calving, standardized; ddry $2=$ mean days dry, standardized; tci2 = mean Transition Cow Index, standardized; ecm $2=$ mean $3.5 \%$ ECM, standardized; drycure $2=$ proportion of dry period IMI cured (SCC at last test of previous lactation $>200,000$ and SCC at first test of current lactation $<200,000$ ), standardized. Color version available online.

middle of the groups, with many statistical similarities to both the best and worst performing groups.

\section{DISCUSSION}

The purpose of using PCA and CA on this DHI data set was to segregate herds by performance, based on multiple covariates, without biasing the selection toward larger herds or any other single variable. The PCA and CA successfully grouped variables and farms, respectively, using multiple variables simultaneously and without apparently completely biasing groups to- ward any single variable. Some calculated variables of DHI performance were selected by PCA as more useful to describe herds than the components of such calculated variables (e.g., ECM vs. milk fat percent and milk protein percent), whereas other calculated variables with related components were retained after PCA for CA (e.g., TCI and milk production).

Previous studies have shown strong correlation between herd size and DHI variable performance (Lucy, 2001; Oleggini et al., 2001), and mean herd size was selected as a useful variable by PCA for cluster analysis. Whereas numerical differences in mean herd size 


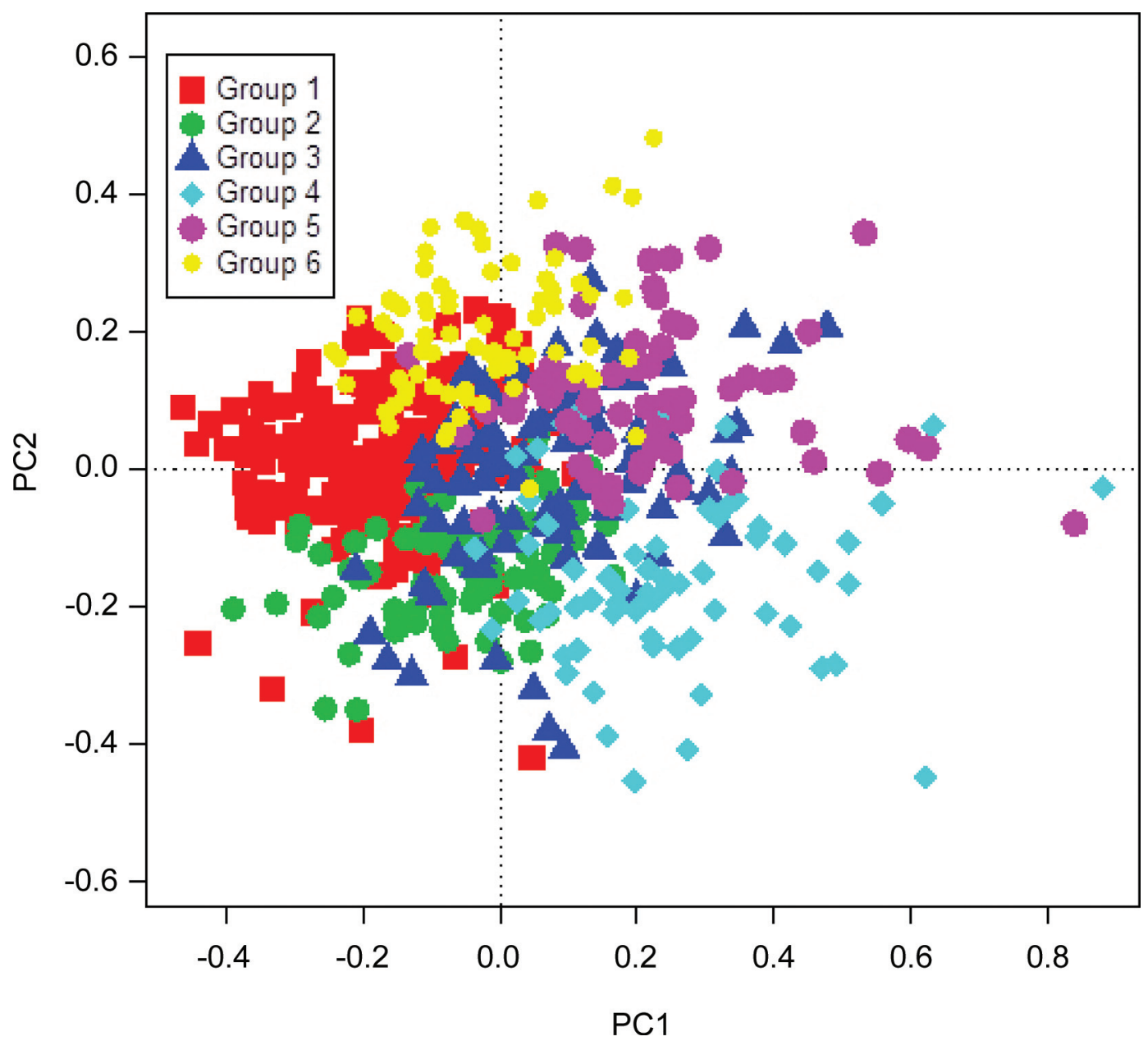

Figure 2. Biplot in the principal component 1 (PC1) and 2 (PC2) plane depicting the groups of herds through cluster analysis. Each dot represents 1 herd and each group is represented by a different shape or shade. Color version available online.

were observed between groups in the current study, there were both smaller and larger herds distributed throughout the groups, indicating that herd size was important, but not the only factor for grouping herds through CA.

The mean performance of the groups in each PCAselected variable depicted common associations with DHI variables and stereotypes of dairy management styles that can be observed in the field. Differences in herd performance within each group likely result from different patterns of management.

Group 1 was characterized by the best-performing herds in this data set as described by the PCA-selected variables. These herds were middle-of-the-range in size, with a mean of 581 cows, yet included herds with just 201 cows and as many as 2,721 cows. These herds had the highest mean ECM production per cow and the best performance in all mean somatic cell and udder infection status variables. With primarily 3-times daily milking in group 1, higher milk production and lower SCC would be expected based on previous reports, particularly with larger herd sizes (Smith et al., 2002; Hart et al., 2013). However, increased milking frequency would have been expected to have no effect on measures of reproductive performance (Amos et al., 1985; DePeters et al., 1985; Gisi et al., 1986) or a detrimental effect (Smith et al., 2002), yet group 1 mean DIM was among the lowest of all groups. Group 1 had the second lowest mean AGE1. The results of Krpálková et al. (2014) as well as Ettema and Santos, (2004) support the balance group 1 herds achieved in intensity of heifer rearing and subsequent milk yield and reproductive performance, that although herds with high milk production have the lowest AGE1, herds with the lowest AGE1 have decreased conception rates in subsequent lactations. Group 1 demonstrated the lowest mean death rate and mean proportion of cows died by 60 DIM. Whereas increased herd size has been 
Table 2. Pearson correlations between 16 principal component analysis (PCA)-selected, 2011 mean test-day DHI variables for 557 Upper Midwest dairies of mean $\geq 200$ cows on test categorized into 6 groups using cluster analysis

\begin{tabular}{|c|c|c|c|c|c|c|c|c|c|c|c|c|c|c|c|c|}
\hline Item & $\begin{array}{l}\text { Milk } \\
\text { freq }\end{array}$ & $\begin{array}{c}\text { Herd } \\
\text { size }\end{array}$ & LACT1 & ECM & DIM & DDRY & AGE1 & TCI & $\begin{array}{l}\text { Milk } \\
\text { peak } \\
\text { ratio }\end{array}$ & LSCS & NINF & INF1 & DC & CULL & DIED & DIED60 \\
\hline Milk freq. & 1.00 & & & & & & & & & & & & & & & \\
\hline Herd size & 0.27 & 1.00 & & & & & & & & & & & & & & \\
\hline LACT1 & 0.14 & 0.15 & 1.00 & & & & & & & & & & & & & \\
\hline ECM & 0.34 & 0.11 & 0.03 & 1.00 & & & & & & & & & & & & \\
\hline DIM & 0.04 & -0.10 & -0.08 & -0.05 & 1.00 & & & & & & & & & & & \\
\hline DDRY & -0.10 & -0.11 & -0.10 & -0.03 & -0.27 & 1.00 & & & & & & & & & & \\
\hline AGE1 & -0.28 & -0.27 & -0.21 & -0.23 & 0.29 & 0.10 & 1.00 & & & & & & & & & \\
\hline TCI & -0.02 & -0.05 & -0.09 & 0.60 & -0.24 & 0.16 & -0.10 & 1.00 & & & & & & & & \\
\hline Milk peak ratio & 0.02 & -0.09 & 0.05 & -0.23 & 0.33 & -0.27 & 0.25 & -0.37 & 1.00 & & & & & & & \\
\hline LSCS & -0.12 & 0.03 & -0.02 & -0.36 & 0.33 & -0.10 & 0.19 & -0.33 & 0.33 & 1.00 & & & & & & \\
\hline NINF & -0.05 & 0.09 & 0.05 & -0.37 & 0.26 & -0.10 & 0.12 & -0.37 & 0.29 & 0.89 & 1.00 & & & & & \\
\hline INF1 & -0.22 & -0.07 & 0.07 & -0.39 & 0.13 & 0.03 & 0.28 & -0.29 & 0.26 & 0.61 & 0.60 & 1.00 & & & & \\
\hline $\mathrm{DC}$ & 0.31 & 0.20 & 0.06 & 0.34 & -0.12 & -0.03 & -0.30 & 0.16 & -0.23 & -0.35 & -0.30 & -0.50 & 1.00 & & & \\
\hline CULL & 0.07 & 0.15 & 0.39 & 0.01 & -0.01 & -0.05 & -0.15 & -0.11 & 0.03 & 0.12 & 0.17 & 0.11 & 0.09 & 1.00 & & \\
\hline DIED & 0.09 & 0.09 & -0.04 & -0.11 & 0.24 & -0.02 & 0.05 & -0.20 & 0.14 & 0.29 & 0.29 & 0.17 & -0.06 & 0.20 & 1.00 & \\
\hline DIED60 & 0.00 & 0.02 & -0.12 & -0.09 & 0.15 & -0.01 & 0.07 & -0.11 & 0.07 & 0.18 & 0.16 & 0.14 & -0.03 & 0.12 & 0.85 & 1.00 \\
\hline
\end{tabular}

${ }^{1}$ Milk freq = milking frequency of the herd, times per day; LACT1 = proportion of the herd as primiparous cows; $\mathrm{ECM}=3.5 \% \mathrm{ECM} ; \mathrm{NM} \$=$ genetic evaluation of herd net merit; DDRY = days dry; AGE1 = age at first calving; TCI Transition Cow Index; milk peak ratio = ratio of peak test day milk production of primiparous to multiparous cows; first tes $F: P \geq 1.4=$ proportion of herd with milk fat-to-protein ratio greater than or equal to 1.4 at first test; LSCS = linear somatic cell score (log SCC); NINF $=$ proportion of herd with a new IMI (previous test day SCC $<200,000$ and current test day SCC $>200,000$ ); CINF $=$ proportion of herd with a chronic IMI (previous test day SCC $>200,000$ and current test day SCC $>200,000$ ); INF1 = proportion of herd with a new IMI at first test (SCC at last test of previous lactation $<200,000$ and SCC at first test of current lactation $>200,000$ ); DC $=$ proportion of dry period IMI cured (SCC at last test of previous lactation $>200,000$ and SCC at first test of current lactation $<200,000$ ); CULL $=$ proportion of herd culled; $\mathrm{DIED}=$ proportion of herd that died; DIED $60=$ proportion of herd that died by 60 DIM. 
Table 3. Least squares means and results of multivariate ANOVA of 16 principal component analysis (PCA)-selected, 2011 mean test-day DHI variables for 557 Upper Midwest dairies of mean $\geq 200$ cows on test categorized into 6 groups using cluster analysis

\begin{tabular}{|c|c|c|c|c|c|c|}
\hline DHI variable ${ }^{1}$ & $\begin{array}{c}\text { Group 1 } \\
(\mathrm{n}=171)\end{array}$ & $\begin{array}{l}\text { Group 2 } \\
(\mathrm{n}=86)\end{array}$ & $\begin{array}{l}\text { Group } 3 \\
(\mathrm{n}=97)\end{array}$ & $\begin{array}{l}\text { Group } 4 \\
(\mathrm{n}=67)\end{array}$ & $\begin{array}{l}\text { Group 5 } \\
(\mathrm{n}=62)\end{array}$ & $\begin{array}{l}\text { Group } 6 \\
(\mathrm{n}=74)\end{array}$ \\
\hline Milking frequency & $3.0^{\mathrm{a}}$ & $2.0^{\mathrm{d}}$ & $2.9^{\mathrm{a}}$ & $2.2^{\mathrm{c}}$ & $2.8^{\mathrm{b}}$ & $3.0^{\mathrm{a}}$ \\
\hline $\mathrm{ECM}, \mathrm{kg}$ & $41.7^{\mathrm{a}}$ & $39.4^{\mathrm{b}}$ & $40.0^{\mathrm{ab}}$ & $33.9^{\mathrm{d}}$ & $36.9^{\mathrm{c}}$ & $40.2^{\mathrm{ab}}$ \\
\hline DIM & $182.9^{\mathrm{c}}$ & $179.7^{\mathrm{c}}$ & $195.5^{\mathrm{a}}$ & $189.1^{\mathrm{b}}$ & $192.5^{\mathrm{ab}}$ & $181.8^{\mathrm{c}}$ \\
\hline DDRY & $59.4^{\mathrm{ab}}$ & $59.4^{\mathrm{ab}}$ & $54.7^{\mathrm{c}}$ & $60.7^{\mathrm{a}}$ & $60.8^{\mathrm{a}}$ & $57.0^{\mathrm{bc}}$ \\
\hline Milk peak ratio & $74.4^{\mathrm{c}}$ & $74.1^{\mathrm{c}}$ & $77.8^{\mathrm{a}}$ & $77.6^{\mathrm{a}}$ & $76.4^{\mathrm{ab}}$ & $74.9^{\mathrm{bc}}$ \\
\hline LSCS & $2.2^{\mathrm{d}}$ & $2.3^{\mathrm{d}}$ & $2.6^{\mathrm{c}}$ & $3.0^{\mathrm{a}}$ & $2.8^{\mathrm{b}}$ & $2.7^{\mathrm{c}}$ \\
\hline NINF, $\%$ & $8.7^{\mathrm{c}}$ & $8.9^{\mathrm{c}}$ & $11.9^{\mathrm{b}}$ & $14.7^{\mathrm{a}}$ & $13.9^{\mathrm{a}}$ & $12.6^{\mathrm{b}}$ \\
\hline INF1, \% & $11.0^{\mathrm{e}}$ & $13.7^{\mathrm{d}}$ & $15.7^{\mathrm{c}}$ & $19.9^{\mathrm{a}}$ & $17.8^{\mathrm{b}}$ & $14.5^{\mathrm{cd}}$ \\
\hline $\mathrm{DC}, \%$ & $75.5^{\mathrm{a}}$ & $66.4^{\mathrm{b}}$ & $63.9^{\mathrm{b}}$ & $56.5^{\mathrm{c}}$ & $63.7^{\mathrm{b}}$ & $71.5^{\mathrm{a}}$ \\
\hline CULL, \% & $33.5^{\mathrm{b}}$ & $36.1^{\mathrm{b}}$ & $35.9^{\mathrm{b}}$ & $32.6^{\mathrm{b}}$ & $40.0^{\mathrm{a}}$ & $43.0^{\mathrm{a}}$ \\
\hline DIED, $\%$ & $5.7^{\mathrm{cd}}$ & $5.7^{\mathrm{cd}}$ & $6.3^{\mathrm{bc}}$ & $4.9^{\mathrm{d}}$ & $12.4^{\mathrm{a}}$ & $7.6^{\mathrm{b}}$ \\
\hline
\end{tabular}

${ }^{\mathrm{a} e}$ Least squares means within a row with different superscripts differ $(P<0.05)$.

${ }^{1} \mathrm{LACT} 1=$ proportion of the herd as primiparous cows; ECM $=3.5 \% \mathrm{ECM}$; NM $\$$ genetic evaluation of herd net merit; DDRY = days dry; AGE1 = age at first calving; TCI = Transition Cow Index; milk peak ratio = ratio of peak test day milk production of primiparous to multiparous cows; LSCS = linear somatic cell score (log SCC); NINF = proportion of herd with a new IMI (previous test day SCC <200,000 and current test day SCC >200,000); CINF $=$ proportion of herd with a chronic IMI (previous test day SCC $>200,000$ and current test day SCC $>200,000$ ); INF1 = proportion of herd with a new IMI at first test (SCC at last test of previous lactation $<200,000$ and SCC at first test of current lactation $>200,000$ ); DC $=$ proportion of dry period IMI cured (DC; SCC at last test of previous lactation $>200,000$ and SCC at first test of current lactation $<200,000)$; CULL $=$ proportion of herd culled; DIED = proportion of herd that died; DIED60 = proportion of herd that died by 60 DIM.

associated with increased death rate (Nørgaard et al., 1999; Smith et al., 2000; Alvåsen et al., 2012), increased milk production has been associated with decreased death rate (Alvåsen et al., 2012) and management factors improving milk yield in group 1 herds may also be positively influencing dairy cow survival in these herds. Mean TCI was second best in group 1 as well, which may have translated into improved fresh cow health and higher milk yield in these herds (Nordlund, 2006). Group 1 herds could very likely be established herds with a focus on animal care and use of technology to enhance performance and sustainability.

The primary differences of group 2 from group 1 were milking frequency, mean herd size, ECM, new IMI at first test, and DC (see Table 1). Yet group 2 produced a mean of just $6 \%$ less ECM per cow per day on only twice-daily milking opposed to the vast majority of herds in group 1 milking 3 times daily. In comparison, Smith et al. (2002) found that large herds of $\geq 250$ cows milking 3 times daily from 1998 through 2000 out-produced large herds milking twice daily by 12 to 14\% ECM. Although group 2 had smaller mean herd size, they achieved similar high levels of performance in milk production, udder health, reproduction, and removal variables as group 1, in contrast to previously reported analyses of herd records categorized by herd size (Nørgaard et al., 1999; Smith et al., 2000; Oleggini et al., 2001).
Group 6 herds could be characterized as larger herds with a high proportion of primiparous cows, possibly linked to expansion in herd size or reliance on enhanced breeding technologies resulting in a plentiful supply of replacement heifers. These herds also had the lowest mean AGE1 and mean DIM among all groups, the second-highest milk production, and the highest LSM DC of all 6 groups. However, the modest performance in LSM TCI and highest cull and second-highest died rate are alarming, suggesting that this group may be struggling in some areas of management, such as fresh cow health. Group 6 herds almost match the pattern expected of larger herd sizes, that milk production increases, SCC decreases, calving intervals tighten, and culling and death rates increase as previously demonstrated and reviewed by others (Nørgaard et al., 1999; Smith et al., 2000; Oleggini et al., 2001). This demonstrates that although herd size influenced the formation of group 6 , it was not the primary driver of performance outcome among its herds.

In contrast to groups 1, 2, and 6, group 5 had the poorest or second-poorest performance among all of the groups. These herds were generally larger than herds in groups 2, 3, and 4, yet demonstrated lower mean ECM and the worst performance in reproductive management, genetics, transition cow management, and milk quality. These herds had the second-highest mean cull rate, with the highest mean death loss of $12.4 \pm 3.6 \%$ 
overall and $5.7 \pm 2.0 \%$ of cows dead by 60 DIM. The mean death rate in group 5 was nearly twice that of a recent study of DHI data from 2,054 herds of $>100$ cows primarily located in the eastern half of the United States (6.6\%; Pinedo et al., 2010) and that others have found for herds of similar size and milk production level (6-7\%; Smith et al., 2000). Mortality rate by 60 DIM for group 5 is similar to previous studies of DHI data in other regions (4-7\%; Hadley et al., 2006; Dechow and Goodling, 2008). Even though group 5 herds were similar in size to group 1, they provided a stark contrast in performance, suggestive of a difference in management approach with higher cull rates and replacement efforts likely associated with health problems during early lactation worthy of future investigation.

Whereas group 4 herds had the lowest performance in mean milk production, reproduction, and milk quality, as well as second-lowest performance in mean TCI, this group of herds also had the lowest mean levels of culling and death rates among all of the groups. Others have previously shown the association between smaller herd size or lower milk production with lower risk of culling or death rate (Bascom and Young, 1998; Smith et al., 2000; Dechow and Goodling, 2008), yet group 4 herds on average would be considered high-producing herds of high-medium to large in size compared with these studies. Dechow and Goodling (2008) found no difference in milk yield between low- and high-survival herds, but did see an association of lower SCS among high-survival herds in contrast to the combination of poorer udder health and low culling rates of group 4 herds. Reproductive failure has a strong influence on survivability of the individual cow (De Vries et al., 2010) and mortality rate at the herd-level (McConnel et al., 2008; Raboisson et al., 2011), yet group 4 was characterized as herds with poorer reproductive performance, low culling, and low death rates. Weigel et al. (2003) found that twice-daily milking was associated with decreased culling rates among herds of an average size of 252 cows, which fits with the characterization of group 4 herds given the available data for our study. The performance of this group highlights the usefulness of CA considering multiple variables simultaneously for grouping herds. Overall herd performance cannot be judged using 1 or 2 performance characteristics, such as culling rate or milk production. Whereas in some situations lower culling rates may represent improved performance, in others - as indicated by group 4-it may actually hinder performance in other areas. Group 4 herds, with the smallest mean herd size, may be retaining cows in the herd too long, resulting in decreased milk production, milk quality, and reproductive performance.
The performance characteristics of group 3 were unclear. This group perhaps represented a catch-all for herds that did not fall into one of the more well-defined categories, could be defined by a specific dairy herd stereotype of the average dairy, or contained herds related by several factors not measured by the variables included in the CA. Whereas these herds demonstrated high levels of milk production, they lagged in reproductive performance with the longest DIM and second oldest AGE1. Milk quality variables were mediocre to poor when compared with the other groups. Still, mean culling and death loss for group 3 was nearly half of that of group 5. These generally small to midsize herds of 211 to 810 cows may have used management practices to improve production, such as milking 3 times daily and short dry periods, but perhaps fell short of the performance of other groups as a result of management and facility characteristics unavailable for this analysis.

Although benchmarking herds against the top performance of other herds in the industry can be useful for comparison and adoption of current best practices, benchmarking is inherently flawed in that goal setting is done relative to others' performance rather than to an independent standard. The use of benchmarking to find best practices of production can result in reliance on others to find and adapt innovative methods first, rather than encouraging creative problem solving within an organization (Henczel, 2002). Also, it is questionable how herds of differing sizes and management capabilities can compare themselves to each other when their organizational and economic structures are obviously different. Further, as demonstrated in our study, no one variable can truly describe a dairy's performance as a whole. Cluster analysis avoids problems of using a single variable and inappropriate comparison by allowing a probability model to sort herds based on many characteristics simultaneously and in an outcomeindependent way.

Statistical tools such as CA should be further assessed for their usefulness and be used to describe and categorize herds within similar over-parameterized data sets. The resulting information could help focus educational or marketing efforts toward farms most in need of attention in multiple areas of production management, and potentially draw attention to patterns rather than individual components of management that result in an overall healthy and productive dairy herd.

\section{CONCLUSIONS}

Both PCA and CA were used successfully to sort dairy herds into categories using multiple variables as selection parameters without preconceived outcomes. 
A highest-performing group was identified, along with 2 additional groups of similar or good overall performance resulting in patterns of dairy herd performance recognized by the industry. A poorest-performing group overall was also identified. Although herds did tend to cluster by mean herd size and milking frequency, we noted a wide range of herd sizes, ECM, and nearly every variable in each resulting group, avoiding categorization of herds based upon singular or only a few variables. Ultimately, the $\mathrm{CA}$ performed in this data set provided groupings of herds by differences in performance based on multiple characteristics worthy of future investigation and characterization. The outcome deserves further study into management practices associated with the DHI profile of groups of large dairy herds of variable levels of overall success. This grouping strategy can serve farmers and their consultants in pattern recognition of herd performance, resulting in objectives for innovative improvements based on multiple variables at one time. Combined with knowledge of housing type and management characteristics, this approach may yield improved mechanisms for information transfer and technological improvements in herd efficiency and productivity.

\section{ACKNOWLEDGMENTS}

The authors appreciate the assistance of personnel and access to dairy herd data at AgSource Cooperative Services (Verona, WI), and for statistical support provided by Cecile Ane and Nicholas Keuler (Department of Statistics, University of Wisconsin-Madison).

\section{REFERENCES}

Alvarez, A., J. del Corral, D. Solís, and J. A. Pérez. 2008. Does intensification improve the economic efficiency of dairy farms? J. Dairy Sci. 91:3693-3698.

Alvåsen, K., M. Jansson Mörk, C. Hallén Sandgren, P. T. Thomsen, and U. Emanuelson. 2012. Herd-level risk factors associated with cow mortality in Swedish dairy herds. J. Dairy Sci. 95:4352-4362.

Amos, H. E., T. Kiser, and M. Loewenstein. 1985. Influence of milking frequency on productive and reproductive efficiencies of dairy cows. J. Dairy Sci. 68:732-739.

Bascom, S. S., and A. J. Young. 1998. A summary of the reasons why farmers cull cows. J. Dairy Sci. 81:2299-2305.

Borcard, D. 2011. Numerical Ecology with R. Springer, New York, NY.

Bramley, E., I. J. Lean, W. J. Fulkerson, M. A. Stevenson, A. R. Rabiee, and N. D. Costa. 2008. The definition of acidosis in dairy herds predominantly fed on pasture and concentrates. J. Dairy Sci. 91:308-321.

Dechow, C. D., and R. C. Goodling. 2008. Mortality, culling by sixty days in milk, and production profiles in high- and low-survival Pennsylvania herds. J. Dairy Sci. 91:4630-4639.

DePeters, E. J., N. E. Smith, and J. Acedo-Rico. 1985. Three or two times daily milking of older cows, and first lactation cows for entire lactations. J. Dairy Sci. 68:123-132.

De Vries, A., J. D. Olson, and P. J. Pinedo. 2010. Reproductive risk factors for culling and productive life in large dairy herds in the eastern United States between 2001 and 2006. J. Dairy Sci. 93:613-623.

Enevoldsen, C., J. Hindhede, and T. Kristensen. 1996. Dairy herd management types assessed from indicators of health, reproduction, replacement, and milk production. J. Dairy Sci. 79:12211236 .

Enevoldsen, C., J. T. Sørensen, I. Thysen, C. Guard, and Y. T. Gröhn. 1995. A diagnostic and prognostic tool for epidemiologic and economic analyses of dairy herd health management. J. Dairy Sci. 78:947-961.

Ettema, J. F., and J. E. P. Santos. 2004. Impact of age at calving on lactation, reproduction, health, and income in first-parity Holsteins on commercial farms. J. Dairy Sci. 87:2730-2742.

Galligan, D. 2006. Economic assessment of animal health performance. Vet. Clin. North Am. Food Anim. Pract. 22:207-227.

Galligan, D. T. 1999. The economics of optimal health and productivity in the commercial dairy. Rev. Sci. Tech. 18:512-519.

Gisi, D. D., E. J. DePeters, and C. L. Pelissier. 1986. Three Times daily milking of cows in California dairy herds. J. Dairy Sci. 69:863-868.

Hadley, G. L., C. A. Wolf, and S. B. Harsh. 2006. Dairy cattle culling patterns, explanations, and implications. J. Dairy Sci. 89:22862296.

Hart, K. D., B. W. McBride, T. F. Duffield, and T. J. DeVries. 2013. Effect of milking frequency on the behavior and productivity of lactating dairy cows. J. Dairy Sci. 96:6973-6985.

Henczel, S. 2002. Benchmarking-Measuring and comparing for continuous improvement. Inf. Outlook 6:12-20.

Kirk, J. H., B. McCowan, E. R. Atwill, K. S. Glenn, G. E. Higginbotham, C. A. Collar, A. Castillo, B. A. Reed, N. G. Peterson, and J. S. Cullor. 2005. Association of minimum inhibitory concentration cluster patterns with dairy management practices for environmental bacteria isolated from bulk tank milk. J. Dairy Sci. 88:3710-3720.

Krpálková, L., V. E. Cabrera, J. Kvapilík, J. Burdych, and P. Crump. 2014. Associations between age at first calving, rearing average daily weight gain, herd milk yield and dairy herd production, reproduction, and profitability. J. Dairy Sci. 97:6573-6582.

Lucy, M. C. 2001. Reproductive loss in high-producing dairy cattle: Where will it end? J. Dairy Sci. 84:1277-1293.

Mayer, M. W., and D. W. Kammel. 2008. Dairy modernization survey. Accessed Jun. 28, 2013. http://cdp.wisc.edu/pdf/Dairy\%20Modernization\%20Paper\%202008.pdf.

McConnel, C. S., J. E. Lombard, B. A. Wagner, and F. B. Garry. 2008. Evaluation of factors associated with increased dairy cow mortality on United States dairy operations. J. Dairy Sci. 91:1423-1432.

Nordlund, K. N. 2006. Transition cow index. Pages 139-143 in 39th Proc. Am. Assoc. Bovine Practitioners. St. Paul, MN. Frontier Printers, Stillwater, OK.

Nørgaard, N. H., K. M. Lind, and J. F. Agger. 1999. Cointegration analysis used in a study of dairy-cow mortality. Prev. Vet. Med. 42:99-119.

Oleggini, G. H., L. O. Ely, and J. W. Smith. 2001. Effect of region and herd size on dairy herd performance parameters. J. Dairy Sci. 84:1044-1050.

Pecsok, S. R., B. J. Conlin, G. R. Steuernagel, and M. L. McGilliard. 1992. The effect of herd milk production on scoring dairy herd improvement performance measures. J. Dairy Sci. 75:317-325.

Pinedo, P. J., A. De Vries, and D. W. Webb. 2010. Dynamics of culling risk with disposal codes reported by Dairy Herd Improvement dairy herds. J. Dairy Sci. 93:2250-2261.

Raboisson, D., E. Cahuzac, P. Sans, and G. Allaire. 2011. Herd-level and contextual factors influencing dairy cow mortality in France in 2005 and 2006. J. Dairy Sci. 94:1790-1803.

Smith, J. W., L. O. Ely, and A. M. Chapa. 2000. Effect of region, herd size, and milk production on reasons cows leave the herd. J. Dairy Sci. 83:2980-2987.

Smith, J. W., L. O. Ely, W. M. Graves, and W. D. Gilson. 2002. Effect of milking frequency on DHI performance measures. J. Dairy Sci. 85:3526-3533. 
USDA, National Agricultural Statistics Service. 2010. Wisconsin dairy producer survey 2010. Accessed May 7, 2013. http://www.nass. usda.gov/Statistics_by_State/Wisconsin/Publications/Dairy/ Dairy_OP_Release_10.pdf.

USDA, National Agricultural Statistics Service. 2012. Milk production, measured in percent by size group. Accessed Oct. 3, 2014. http://quickstats.nass.usda.gov/results/6D9F2D7A-D25A-3AC5866B-EF3F5C1B57EE?pivot=short_desc.

von Keyserlingk, M. A. G., N. P. Martin, E. Kebreab, K. F. Knowlton, R. J. Grant, M. Stephenson, C. J. Sniffen, J. P. Harner III, A. D.
Wright, and S. I. Smith. 2013. Invited review: Sustainability of the US dairy industry. J. Dairy Sci. 96:5405-5425.

Weigel, K. A., R. W. Palmer, and D. Z. Caraviello. 2003. Investigation of factors affecting voluntary and involuntary culling in expanding dairy herds in Wisconsin using survival analysis. J. Dairy Sci. $86: 1482-1486$

Weigel, K. A., and R. Rekaya. 2000. A multiple-trait herd cluster model for international dairy sire evaluation. J. Dairy Sci. 83:815-821.

\section{APPENDIX}

Table A1. Herd mean test-day DHI data for 2011 for all AgSource herds, before removing herds with incomplete records, herds with a mean test-day herd size of $<200$ cows, and herds outside of the Upper Midwest; after data editing and submission to principal component analysis, 16 variables $(*)$ were selected for use in cluster analysis based on explaining above average variance of 557 Upper Midwest dairies of $\geq 200$ cows mean on test

\begin{tabular}{|c|c|c|c|}
\hline DHI variable ${ }^{1}$ & $\mathrm{~N}$ & Mean \pm SD & Median \\
\hline *Milking frequency & 4,190 & $2.1 \pm 0.3$ & 2.0 \\
\hline *Herd size & 4,190 & $155.4 \pm 339.4$ & 70.9 \\
\hline *LACT1 & 4,184 & $36.8 \pm 8.8$ & 36.6 \\
\hline Milk fat, $\%$ & 4,190 & $3.8 \pm 0.4$ & 3.8 \\
\hline Milk protein, \% & 4,190 & $3.1 \pm 0.2$ & 3.1 \\
\hline *ECM, kg & 4,186 & $34.9 \pm 6.0$ & 35.4 \\
\hline $\mathrm{NM} \$$ & 3,414 & $58.2 \pm 77.2$ & 63.2 \\
\hline *DIM & 4,190 & $191.3 \pm 29.3$ & 186.2 \\
\hline *DDRY & 4,156 & $63.6 \pm 15.6$ & 61.6 \\
\hline *AGE1, mo & 4,184 & $26.5 \pm 2.9$ & 25.8 \\
\hline *TCI, $\mathrm{kg}$ & 4,154 & $24.2 \pm 389.5$ & 29.3 \\
\hline *Milk peak ratio & 4,177 & $76.8 \pm 5.9$ & 76.2 \\
\hline First test $F: P \geq 1.4, \%$ & 4,172 & $40.3 \pm 17.8$ & 38.2 \\
\hline *LSCS & 4,177 & $2.8 \pm 0.6$ & 2.7 \\
\hline$*$ NINF, $\%$ & 4,177 & $13.0 \pm 5.7$ & 12.0 \\
\hline CINF, $\%$ & 4,177 & $58.0 \pm 12.1$ & 59.4 \\
\hline *INF1, \% & 4,177 & $17.1 \pm 8.2$ & 16.3 \\
\hline$* \mathrm{DC}, \%$ & 4,177 & $40.0 \pm 21.4$ & 38.9 \\
\hline *CULL, \% & 4,188 & $35.6 \pm 13.1$ & 35.4 \\
\hline *DIED, \% & 4,188 & $5.8 \pm 5.2$ & 4.8 \\
\hline *DIED $60, \%$ & 4,188 & $2.2 \pm 2.6$ & 1.7 \\
\hline Stillborn calves, $\%$ of births & 3,736 & $7.5 \pm 9.1$ & 6.7 \\
\hline
\end{tabular}

${ }^{1} \mathrm{LACT} 1=$ proportion of the herd as primiparous cows; $\mathrm{ECM}=3.5 \% \mathrm{ECM} ; \mathrm{NM} \$=$ genetic evaluation of herd net merit; DDRY = days dry; AGE1 = age at first calving; TCI $=$ Transition Cow Index; milk peak ratio $=$ ratio of peak test day milk production of primiparous to multiparous cows; first test $F: P \geq 1.4=$ proportion of herd with milk fat-to-protein ratio greater than or equal to 1.4 at first test; LSCS $=$ linear somatic cell score $(\log \mathrm{SCC}) ; \mathrm{NINF}=$ proportion of herd with a new IMI (previous test day SCC $<200,000$ and current test day SCC >200,000); CINF = proportion of herd with a chronic IMI (previous test day SCC $>200,000$ and current test day SCC $>200,000$ ); INF1 = proportion of herd with a new IMI at first test (SCC at last test of previous lactation $<200,000$ and SCC at first test of current lactation $>200,000$ ); DC = proportion of dry period IMI cured (SCC at last test of previous lactation $>200,000$ and SCC at first test of current lactation $<200,000$ ); $\mathrm{CULL}=$ proportion of herd culled; DIED $=$ proportion of herd that died; DIED60 = proportion of herd that died by 60 DIM. 